\title{
A proposed waist-to-height ratio (WtHR) cutoff point for metabolic risk in Brazilian Turner syndrome patients
}

\section{Uma proposta de ponto de corte da relação cintura/altura (C/A) como marcador de risco metabólico em pacientes com síndrome de Turner}

Samantha Dodt Farias ${ }^{1}$. Eveline Gadelha Pereira Fontenele ${ }^{2}$. Rosana Quezado ${ }^{3}$. Ana Rosa Pinto Quidute ${ }^{4}$. Ludmilla Aline Guimarães Moreira Farias ${ }^{5}$. Tamires Morita ${ }^{6}$. Camila Sâmea Monteiro Bezerra ${ }^{6}$.

1 Endocrine fellow at Hospital Universitário Walter Cantídio (HUWC), Fortaleza, Ceará, Brasil. 2 PhD in Biotechnology, Adjunct Professor, Department of Clinical Medicine, Coordinator of the Center of Multidisciplinary Support for Turner's syndrome patients, Universidade Federal do Ceará (UFC), Fortaleza, Ceará, Brasil. 3 Master's degree in Medical Surgical Sciences, Preceptor Physician at the Endocrinology and Metabolism Service, Hospital Universitário Walter Cantídio (HUWC), Fortaleza, Ceará, Brasil. 4 PhD in Pharmacology, Adjunct Professor, Department of Physiology and Pharmacology, Universidade Federal do Ceará (UFC), Fortaleza, Ceará, Brasil. 5 Endocrinologist, Research fellow of the Endocrinology and Metabolism Service, Hospital Universitário Walter Cantídio (HUWC), Fortaleza, Ceará, Brasil. 6 Intern of Medicine, Hospital Universitário Walter Cantídio (HUWC), Fortaleza, Ceará, Brasil.

\section{ABSTRACT}

Objective: To propose a waist-to-height ratio (WtHR) cutoff point for metabolic risk in Brazilian Turner syndrome (TS) patients. Methods: Retrospective study of anthropometric, clinical and biochemical data related to the metabolic syndrome (MS) of 45 TS patients at a specialized center. The accuracy and area under the receiver operating characteristic (ROC) curve of body mass index (BMI), waist circumference (WC) and WtHR to identify the presence of at least one of the biochemical components of MS were calculated. Results: The average age was 23.8 years (4-61 years), 43\% were overweight and 11\% had MS. At least one component of MS was present in $80 \%$ of the patients, being more common central obesity, low levels of HDL and dysglycemia. None had diabetes. Patients with some of the biochemical changes in MS had higher WtHR than those without metabolic alterations $(0.57$ vs. $0.48, \mathrm{P}=0.001)$. In adult patients $(20-61$ years, $\mathrm{n}=28)$ the WtHR $>0.5$ had $87 \%$ sensitivity and $80 \%$ specificity to identify patients with some component of MS, demonstrating greater accuracy than BMI or WC. Conclusion: We propose a WtHR cutoff point of 0.5 for metabolic risk screening in Brazilian TS patients.

Keywords: Waist-height ratio. Turner syndrome. Metabolic syndrome.

\section{RESUMO}

Objetivo: Propor um ponto de corte da relação cintura-altura $(\mathrm{C} / \mathrm{A})$ para risco metabólico em pacientes brasileiras com síndrome de Turner (ST). Metodologia: Estudo retrospectivo de dados antropométricos, clínicos e bioquímicos relacionados à síndrome metabólica (SM) de 45 pacientes com ST de um centro especializado. A acurácia e a área sob a curva ROC do índice de massa corpórea (IMC), cintura (C) e C/A para identificar presença de no mínimo um dos componentes bioquímicos da SM foram calculadas. Resultados: A idade média foi de 23,8 anos (4-61 anos), 43\% tinham excesso de peso e 11\% tinham SM. Pelo menos um componente da SM estava presente em $80 \%$ das pacientes, sendo mais comuns obesidade central, níveis baixos de HDL e disglicemia. Nenhuma tinha diabetes. Pacientes com alguma das alterações bioquímicas da SM tinham C/A maior que aquelas sem alterações metabólicas $(0,57$ vs. $0,48, \mathrm{P}=0,001)$. Nas pacientes adultas $(20-61$ anos de idade, $\mathrm{n}=28)$ o $\mathrm{C} / \mathrm{A}>0,5$ teve $87 \%$ de sensibilidade e $80 \%$ de especificidade para identificar pacientes com algum componente da SM demonstrando maior acurácia que o IMC ou cintura. Conclusão: Propomos um ponto de corte de C/A de 0,5 para rastreio de risco metabólico em pacientes brasileiras com ST.

Palavras-chave: Relação cintura-altura. Síndrome de turner. Síndrome metabólica.

Autor correspondente: Samantha Dodt Farias, Rua Gustavo Sampaio, 1029, Parquelândia, Fortaleza, Ceará. CEP: 60455-001. Telefone: +55 85 99634-4906. E-mail: samanthadodt@hotmail.com

Conflito de interesses: Não há qualquer conflito de interesses por parte de qualquer um dos autores.

Recebido em: 08 Nov 2017; Revisado em: 21 Fev 2018; Aceito em: 01 Mai 2018. 


\section{INTRODUCTION}

Turner syndrome (TS) is one of the most frequent chromosomal abnormalities and affects around 1:2,000 of female live births. It is caused by partial or complete loss of an X chromosome. Diagnosis is carried out through karyotype analysis and 45, $\mathrm{X}$ monosomy is most commonly found ( $>50 \%$ of cases). There is a wide karyotype variety and some patients present mosaicism with a 46,XX lineage coexisting with a $45, X$ or with structural alteration of the second $\mathrm{X}$ chromosome (deletions of short arm, isochromosome or ring $\mathrm{X}$ chromosome). ${ }^{1}$ The most frequent clinical features are short stature, hypergonadotropic hypogonadism and typical morphological alterations, such as webbed neck, cubitus valgus, low-set ears and a low posterior hairline, among others.

Mortality is high in women with TS and life expectancy is reduced by an average of 13 years compared to the general population. Cardiovascular complications are the leading causes of death. ${ }^{2}$ The patients may present cardiovascular malformations (bicuspid aortic valve, coarctation of the aorta), kidney abnormalities (horseshoe-shaped kidney, renal ectopia), hypothyroidism, hearing loss, osteoporosis and bone fractures. ${ }^{3}$ In this population there is also a higher risk of systemic arterial hypertension, dyslipidemia, elevated liver enzymes, ${ }^{4}$ atherosclerosis and coronary heart disease. Besides, individuals with TS have four-fold increase in the risk of developing diabetes mellitus (DM). ${ }^{5}$ Dyslipidemia, mostly hypertriglyceridemia related to obesity with high LDL and low HDL, is frequent, with a higher prevalence of metabolic syndrome in these patients. ${ }^{6}$

The body mass index (BMI) is commonly used to assess adiposity and estimate metabolic risk. However, this index provides no information on the anatomical distribution of body fat and is unable to differentiate between lean mass and fat mass. Waist circumference is a parameter used to determine central obesity, one of the metabolic syndrome components in adults, for its association with visceral fat. A previous study demonstrated an increased waist circumference in patients with Turner syndrome, which is associated with higher risk of metabolic abnormalities. ${ }^{7}$

However, as TS patients frequently have short stature, the waist circumference may underestimate the visceral fat and its risks.

On the other hand, waist-to-height ratio (WtHR) has been regarded as an effective and practical measurement of central obesity in children. Recent studies suggest that WtHR higher than 0.5 may be an important metabolic risk marker for both children and adults, regardless of sex or ethnicity. ${ }^{8,9}$ Thus, the aim of this study was to estimate a WtHR cutoff point for metabolic risk in Brazilian Turner syndrome (TS) patients.

\section{METHODS}

A retrospective cohort of Turner syndrome outpatients from a tertiary public health service was studied from January 2014 to December 2015. Data collected from medical records in the last medical visit were: i) age, blood pressure, height, weight, body mass index, waist circumference, waist-to-height ratio; ii) karyotype; iii) previous or current use of somatotropin; iv) previous or current use of estrogen; $v$ ) family history of diabetes, hypertension, dyslipidemia and obesity; vi) sedentary lifestyle or smoking; and vii) prevalence of metabolic syndrome or its components according to International Diabetes Federation (IDF) Task Force ${ }^{10}$ criteria for women, during the outpatient follow-up.

Height in centimeters was measured with wall stadiometer (Harpender's technique). Waist circumference (WC) in centimeters was taken with tape measure positioned at the midpoint between the last rib and the superior edge of iliac crest. Weight in kilograms was measured on digital scale. Central obesity was defined as $\mathrm{WC} \geq 80 \mathrm{~cm}$ in adult women (aged $\geq 20 \mathrm{y}$-old), or WtHR $>0.5$ in those aged $<20$ years.

Statistical analysis was carried out using the GraphPad Prism program (v.5.03). Categorical variables were described as frequencies and percentages, and continuous variables as mean \pm standard deviation (SD). The $t$-test was used for comparison between the groups for continuous variables normally distributed and $\chi^{2}$ of Pearson for categorical variables, adopting as significant values $P<0.05$. Considering patients with any biochemical components of metabolic syndrome as 'cases' and those patients without metabolic changes as 'controls', area under the receiver operating characteristic (ROC) curve was calculated for WtHR, waist circumference and BMI. Metabolic risk was designated as the risk to present at least one biochemical component of MS. Accuracy of each cutoff point for metabolic risk was measured and compared. The study was approved by the Research Ethics Committee of our institution (Protocol $\mathrm{n}^{\circ}$. 51418015.0.0000.5045).

\section{RESULTS}

The medical records of $53 \mathrm{TS}$ patients were reviewed. Eight patients were excluded from the study because waist circumference data were missing, or follow-up time was less than 1 year. The chronological age of 45 patients included ranged from 4 to $61 \mathrm{y}$-old (mean $23.7 \pm 10 \mathrm{y}$-old) and the follow-up time ranged from 1 to 46 years (mean $11.9 \pm 8.1$ years). In the last medical visit, 28 patients $(62 \%)$ were adults ( $\geq 20$ y-old).

Monosomy 45,X (47\%) was the karyotype most frequent. All patients had a sedentary lifestyle and did not smoke. Forty-one patients $(91 \%)$ reported positive family history for diabetes, hypertension, dyslipidemia and/or obesity (Table 1). Regarding the weight, 19 (42\%) patients were overweight and $7(16 \%)$ obese. Thirty-six patients $(80 \%)$ had one or more components of metabolic syndrome: central obesity (53\%), HDL-cholesterol $<50 \mathrm{mg} / \mathrm{dL}(36 \%)$, fasting glucose $>100 \mathrm{mg} /$ dL (18\%), triglycerides $>150 \mathrm{mg} / \mathrm{dL}(16 \%), 1$ patient had hypertension, and none had diabetes. Metabolic syndrome was detected in 5 adult patients (11\%) (Table 2). 
Table 1. Descriptive characteristics of Turner syndrome patients $(n=45)$.

\begin{tabular}{lll}
\hline Cathegory & & n (\%) \\
\hline Karyotype & $45, \mathrm{X}$ & $21(47)$ \\
& $45, \mathrm{X} / 46, \mathrm{XX}$ & $9(20)$ \\
Treatment & Mosaic with structural aberrations of the X chromosome & $15(33)$ \\
& Growth hormone & $32(71)$ \\
Family history & Estrogens & $36(80)$ \\
& DM & $27(60)$ \\
& Hypertension & $33(75)$ \\
MS components & Dyslipidemia & $23(53)$ \\
& Obesity & $17(39)$ \\
& Blood glucose $\geq 100 \mathrm{mg} / \mathrm{dL}$ & $8(18)$ \\
& HDL $<50 \mathrm{mg} / \mathrm{dL}$ & $16(36)$ \\
Weight excess & Triglycerides $\geq 150 \mathrm{mg} / \mathrm{dL}$ & $7(15)$ \\
& Systolic BP $\geq 130 \mathrm{mmHg}$ and/or diastolic BP $\geq 85 \mathrm{mmHg}$ & $1(2)$ \\
& Overweight & $12(27)$ \\
& Obesity & $7(16)$ \\
& WC $\geq 80 \mathrm{~cm}($ age $\geq 20$ years) & $15(53)$ \\
& WtHR $>0,5($ age $<20$ years) & $9(53)$ \\
& WtHR $>0.5$ (total) & $31(69)$ \\
\hline
\end{tabular}

BP: blood pressure; DM: diabetes mellitus; HDL: high-density lipoprotein cholesterol; MS: metabolic syndrome; WC: waist circumference; WtHR: waist-to-height ratio.

Table 2. Prevalence of overweight, obesity, hypertension, metabolic changes, pre-MS and MS per age in Turner syndrome patients.

\begin{tabular}{lll}
\hline Variables & Age & \\
\hline & $<20$ years old $(\mathrm{n}=17) \mathrm{n}(\%)$ & $\geq 20$ years old $(\mathrm{n}=28) \mathrm{n}(\%)$ \\
Overweight & $6(35)$ & $13(46)$ \\
Obesity & - & $7(25)$ \\
Blood glucose $\geq 100 \mathrm{mg} / \mathrm{dL}$ & $2(12)$ & $6(21)$ \\
$\mathrm{HDL}<50 \mathrm{mg} / \mathrm{dL}$ & $2(12)$ & $14(28)$ \\
Triglycerides $\geq 150 \mathrm{mg} / \mathrm{dL}$ & $1(6)$ & $6(21)$ \\
Hypertension & - & $1(3.5)$ \\
Pre-MS & $3(18)$ & $9(32)$ \\
MS & - & $5(18)$ \\
\hline
\end{tabular}

HDL: high-density lipoprotein cholesterol; MS: presence of 3 or more metabolic syndrome criteria; Pre-MS: presence of 2 criteria for metabolic syndrome.

Waist-to-height ratio was significantly higher in patients with at least one of the biochemical components of MS when compared to 'controls' (0.57 vs $0.48, P=0.001)$ and there was no significant difference between them in relation to age (Figure 1A-B). Patients with metabolic syndrome were older and had greater WtHR than 'controls' (Figure 1C-D).

Amongst adult patients, 23 (82\%) had one or more metabolic syndrome components. All controls had BMI $\leq 25 \mathrm{~kg} / \mathrm{m}^{2}$ and $\mathrm{WC}<80 \mathrm{~cm}$. BMI, WC and WtHR distribution in 'cases' and 'controls' groups are represented in Figure 2. WtHR was significantly lower in 'controls' (Figure 2A, 0.49 vs $0.60, P=0.04)$. The analysis of the area under the ROC curve showed that WHtR $>0.5$ had more accuracy than BMI $>25 \mathrm{~kg} /$ $\mathrm{m}^{2}$ and $\mathrm{WC} \geq 80 \mathrm{~cm}$ to identify patients with higher metabolic risk, having $87 \%$ sensitivity and $80 \%$ specificity (Table 3 ).

In the sample studied, there was no significant difference in the proportion of patients with or without metabolic syndrome in relation to karyotype, family history or prior or current treatment with somatotropin or estrogen (Figure 3). 
Figure 1. Chronological age in the last medical visit (A) and waist-to height ratio (B) of patients without (not present) or with (present) 1 or more biochemical components of metabolic syndrome; chronological age in the last medical visit (C) and waist-to-height ratio (D) of patients with or without metabolic syndrome.

A

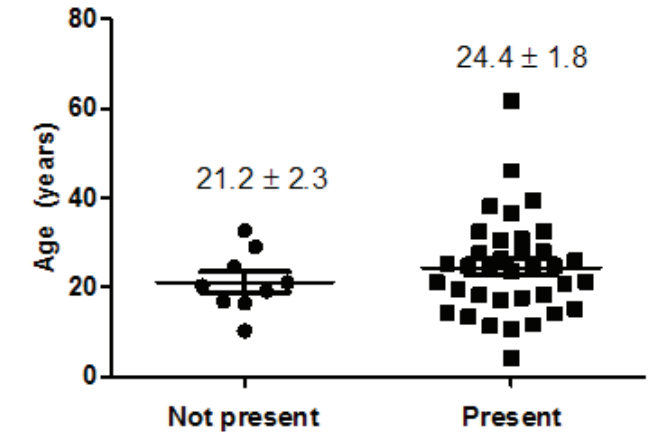

$\mathrm{C}$

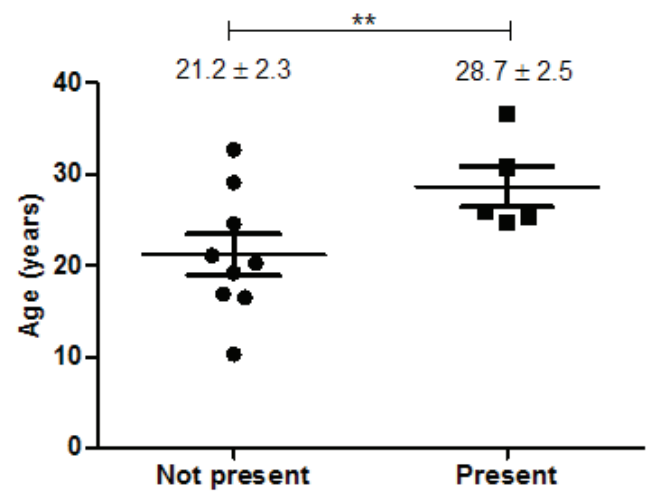

B

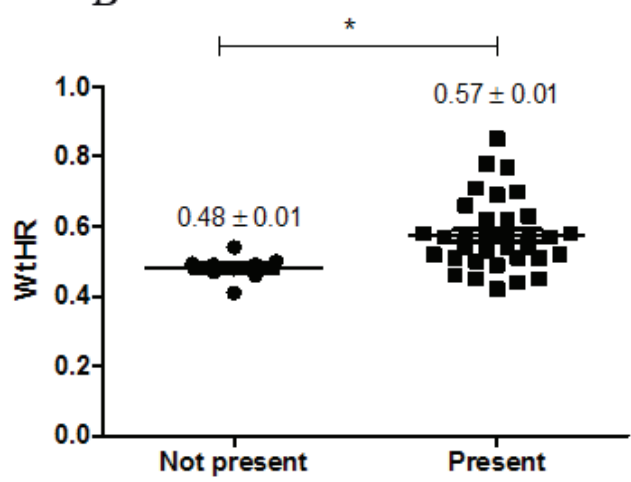

$\mathrm{D}$

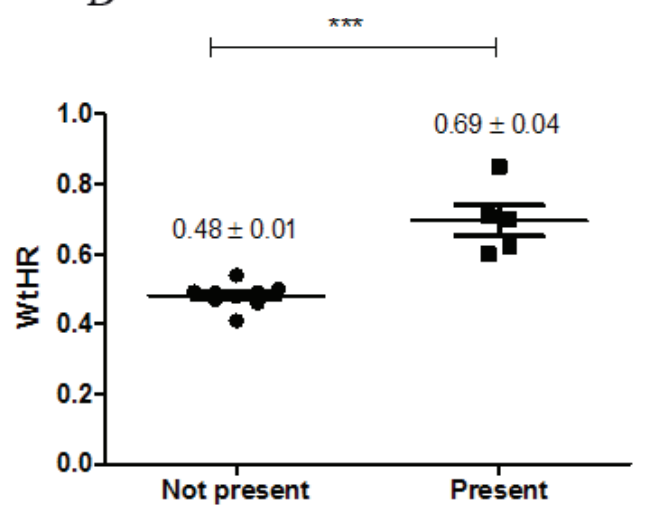

WtHR: waist-to-height ratio; $* \mathrm{P}=0.001 ; * * \mathrm{P}=0.05 ; * * * \mathrm{P}<0.001$

Figure 2. Waist-to-height ratio (A), body mass index (B) and waist circumference (C) of adult patients (age $\geq 20$ years) without (not present) or with (present) one or more biochemical components of metabolic syndrome.

A

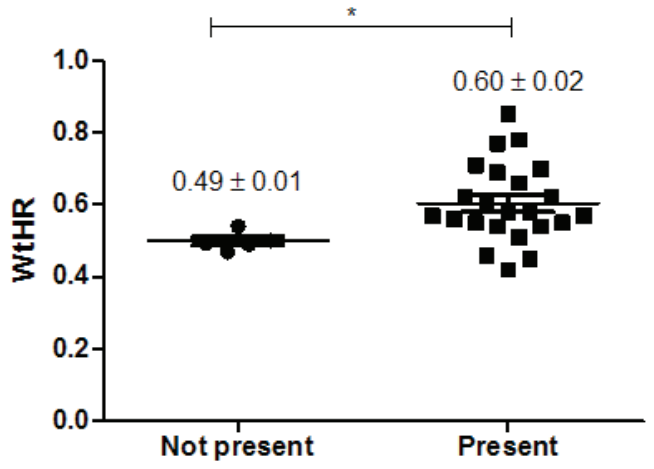

C

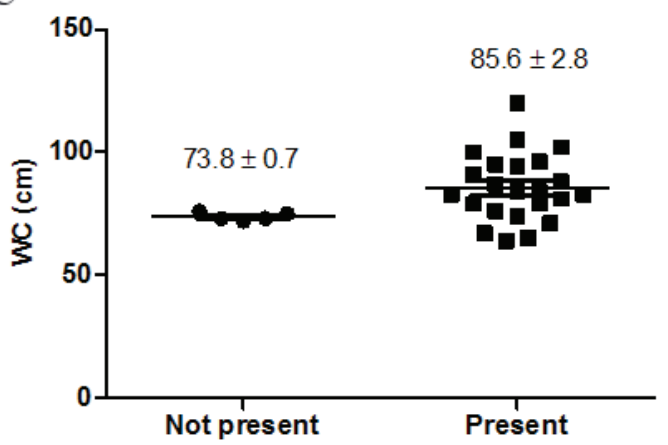

B

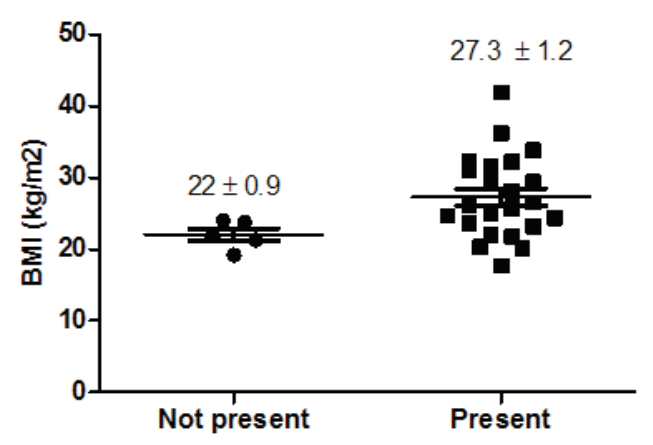

BMI: body mass index; WC: waist circumference; WtHR: waist-to-height ratio. * $P=0.04$ 
Table 3. Analysis of the area under the ROC curve for BMI, WC and WtHR in adult Turner syndrome patients for the prediction of at least one component of metabolic syndrome.

\begin{tabular}{lllll}
\hline & AUC & Sensitivity & Specificity & $P$ \\
\hline BMI $>25 \mathrm{~kg} / \mathrm{m}^{2}$ & 0.813 & $56 \%$ & $100 \%$ & 0.03 \\
$\mathrm{WC} \geq 80 \mathrm{~cm}$ & 0.804 & $65 \%$ & $100 \%$ & 0.03 \\
$\mathrm{WtHR}>0.5$ & 0.852 & $87 \%$ & $80 \%$ & 0.01 \\
\hline
\end{tabular}

AUC: area under the curve; BMI: body mass index; WC: waist circumference; WtHR: waist-to-height ratio.

Figure 3. Frequency of patients without (not present) or with (present) metabolic syndrome, grouped by karyotype (A); family history for DM, hypertension, dyslipidemia and/or obesity (B); treatment with estrogen (C); and treatment with growth hormone (D).

A

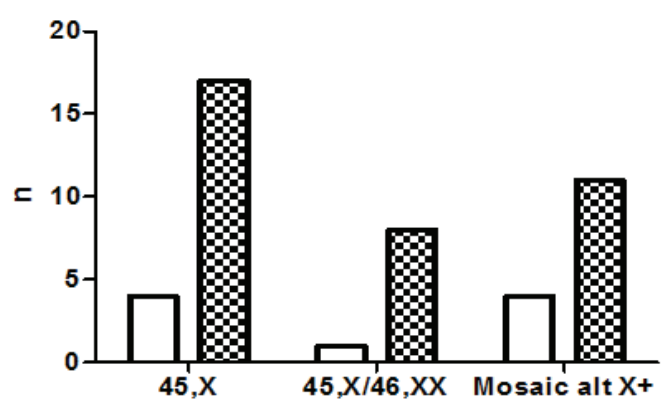

$\mathrm{C}$

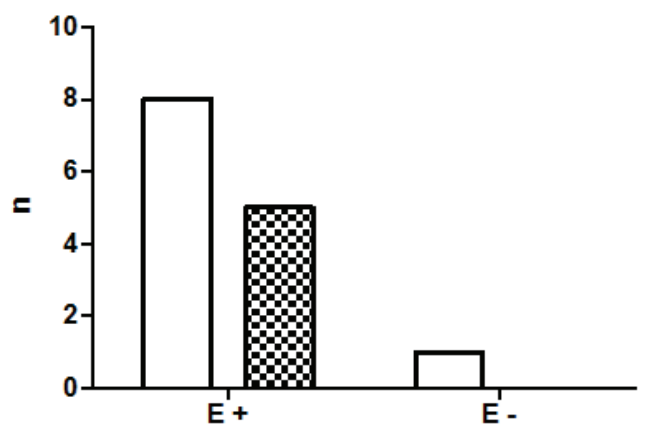

B

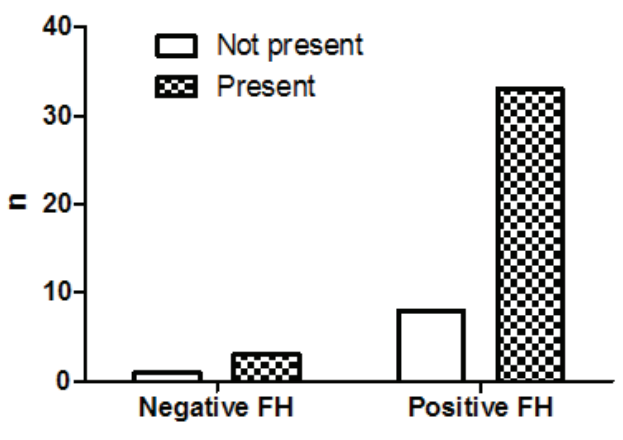

$\mathrm{D}$

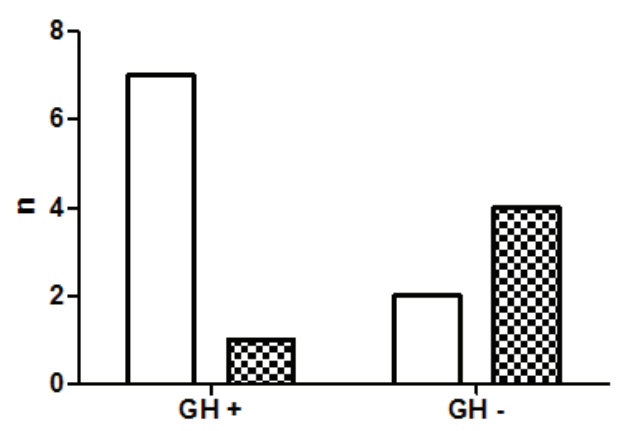

$\mathrm{E}(+/-)$ : current or previous treatment with estrogen (yes/no); $\mathrm{FH}(+/-)$ : family history (positive/negative); $\mathrm{GH}(+/-)$ : current or previous treatment with growth hormone (yes/no).

\section{DISCUSSION}

This study presented the frequency of metabolic abnormalities in a cohort of Turner syndrome outpatients from a tertiary public health service. We detected high prevalence of metabolic abnormalities, mostly in the adult population, in agreement with previous studies that related higher prevalence of cardiovascular risk factors on TS patients. ${ }^{1-3}$

In 2014, according to data published by the Brazilian Ministry of Health, the prevalence of weight excess (BMI $\geq 25 \mathrm{~kg} /$ $\mathrm{m}^{2}$ ), obesity (BMI $\geq 30 \mathrm{~kg} / \mathrm{m}^{2}$ ), diagnosis of hypertension, dyslipidemia and diabetes, on women between 18 and 69 y-old in our city was $50 \%, 17 \%, 25 \%, 20 \%$ and $7.9 \%$, respectively. ${ }^{11}$ We found higher prevalence of dyslipidemia (low HDL and hypertriglyceridemia), equal prevalence of weight excess and obesity, but lower prevalence of hypertension and diabetes in our cohort. These patients also had higher WtHR, although without significant increase of BMI, demonstrating that the higher frequency of metabolic changes in adult patients may be related to increased visceral fat deposition with aging.

The frequency of dysglicemia in our study was lower than a Canadian cohort $\left(26 \%, 8\right.$ to 18 year-aged TS patients) ${ }^{7}$ but higher than observed in a Turkish cohort ${ }^{3}(2.2 \%, 0$ to 18 year-aged TS patients) and an Italian cohort ${ }^{12}(5 \%, 8$ to 46 year-aged TS patients). Calcaterra et al also found a similar prevalence of obesity (18\%), but lower frequencies of low HDL (13\%), hypertriglyceridemia (7\%) and metabolic syndrome (4.7\%) than our study. The authors argue that in addition to overweight and age, genetic and environmental factors would be involved in the development of metabolic syndrome in Turner syndrome patients. ${ }^{12} \mathrm{~A}$ recent study that evaluated cardiovascular risk in 226 health professionals in a Brazilian 
city, metabolic syndrome was detected in $3 \%$ of women 20 to 59 years old, with increased prevalence according to age. ${ }^{13} \mathrm{In}$ our cohort, the prevalence of metabolic syndrome was high and detected only in adult patients (18\%).

The use of growth hormone (GH) to treat short stature in TS patients is already well established. Growth hormone $(\mathrm{GH})$ brings significant metabolic benefits, modifying body composition with increased lean body mass and decreased adiposity. In addition, GH reduces blood pressure, LDL and total cholesterol, without negative effects on insulin resistance. ${ }^{14,15}$ Gonadal dysgenesis and ovarian failure result in estrogen deficiency, being a potential cause of dyslipidemia in TS. Hormone replacement therapy is beneficial to metabolic changes, showing favorable effect on lipid profile, on insulin sensitivity and on endothelial and vascular functions. ${ }^{6,16}$ We observed in our sampling no significant difference in the frequency of metabolic change among untreated patients and those who reported prior/current treatment with GH/estrogen. However, the study design was not suitable for assessing the possible effects of these therapeutic interventions on metabolic profile.

We found a high prevalence of hypertension and diabetes in familial histories, surpassing the expected prevalence in the Brazilian population. ${ }^{11}$ Although there is a high heritability of these pathological conditions involving multiple genes, we did not observe high frequency of these disorders in our patients. Although higher prevalence of dysglycemia and diabetes have been described in patients with isochromosome $\mathrm{X},{ }^{1,2}$ we did not detect significant difference in the frequency of metabolic abnormalities, regarding karyotype.

\section{WtHR and metabolic risk in Turner syndrome patients}

Insulin resistance, dyslipidemia and arterial hypertension are associated with obesity in the general population, however, they may be present in Turner syndrome patients with appropriate

\section{REFERÊNCIAS}

1. Levitsky LL, Luria AH, Hayes FJ, Lin AE. Turner syndrome: update on biology and management across the life span. Curr Opin Endocrinol Diabetes Obes. 2015;22(1):65-72.

2. Castelo-Branco C. Management of turner syndrome in adult life and beyond. Maturitas. 2014;79(4):471-5.

3. Yeşilkaya E, Bereket A, Darendeliler F, Baş F, Poyrazoğlu Ş, Aydın BK, et al. Turner syndrome and associated problems in Turkish children: a multicenter study. J Clin Res Pediatr Endocrinol. 2015;7(1):27-36.

4. Roulot D. Liver involvement in Turner syndrome. Liver Int. 2013;33(1):24-30.

5. Wojcik M, Janus D, Zygmunt-Gorska A, Starzyk J. Insulin resistance in adolescents with Turner syndrome is comparable to obese peers, but the overall metabolic risk is lower due to unknown mechanism. J Endocrinol Invest. 2015;38(3):345-9.

6. Lucaccioni L, Wong SC, Smyth A, Lyall H, Dominiczak A, weight. ${ }^{15}$ In our sampling, $53 \%$ of patients with at least one metabolic syndrome component had normal or low BMI.

Many authors argue that the WC isolated is not satisfactory to predict cardiometabolic risk, since people with the same WC and different height would have probably diverse risks. As TS patients in general have short stature, we infer that WC cutoff point ( $\geq 80 \mathrm{~cm}$ ) proposed by IDF for South American women would not be appropriate in this condition. WtHR was first proposed for diagnosis of abdominal obesity and cardiovascular risk detection, in the early 1990s. ${ }^{17}$ The interest in the effectiveness of this measurement for adults and children has grown a lot in recent decades in different populations and ethnic groups. Meta-analysis data of 300 thousand individuals from studies performed in many countries showed robust statistical evidence of the superiority of WtHR over WC and BMI. This measurement should be adopted for tracking cardiometabolic risk in both sexes ${ }^{18}$. Recently, in a study conducted with an Asian adult population, between 21 and 74 years old, the authors found that $\mathrm{WtHR} \geq 0.5$ indicated increased cardiovascular risk factors in both sexes, more than the combination of BMI and WC. ${ }^{19}$

WtHR proved to be a simple and effective method to screening TS patients. For the first time, we demonstrated in a Brazilian cohort of Turner syndrome adult patients, that WtHR had better accuracy $(85 \%)$ than BMI $(81 \%)$ and WC $(80 \%)$ in detecting the presence of metabolic abnormalities. The low prevalence of metabolic abnormalities and the small number of pediatric patients $(\mathrm{n}=17)$ did not allow us to analyze the accuracy of WtHR, WC and BMI in these patients as we did in the adult sample.

The utilization of proposed cutoff point $>0.5$ for metabolic risk will enable an early intervention and promotion of lifestyle changes thus contributing to improve the survival rate in this population.

Ahmed SF, et al. Turner syndrome-issues to consider for transition to adulthood. Br Med Bull. 2014;113(1):45-58.

7. O’Gorman CS, Syme C, Lang J, Bradley TJ, Wells GD, Hamilton JK. An evaluation of early cardiometabolic risk factors in children and adolescents with Turner syndrome. Clin Endocrinol (Oxf). 2013;78(6):907-13.

8. Khoury M, Manlhiot C, McCrindle BW. Role of the waist/height ratio in the cardiometabolic risk assessment of children classified by body mass index. J Am Coll Cardiol. 2013;62(8):742-51.

9. Kruger HS, Faber M, Schutte AE, Ellis SM. A proposed cutoff point of waist-to-height ratio for metabolic risk in African township adolescents. Nutrition. 2013;29(3):502-7.

10. Alberti KG, Eckel RH, Grundy SM, Zimmet PZ, Cleeman JI, Donato KA, et al. Harmonizing the metabolic syndrome: a joint interim statement of the International Diabetes Federation Task Force on Epidemiology and Prevention; National Heart, Lung, and Blood Institute; American Heart Association; World 
Heart Federation; International Atherosclerosis Society; and International Association for the Study of Obesity. Circulation. 2009;120(16):1640-5.

11. Brasil. Ministério da Saúde. Vigilância de fatores de risco e proteção para doenças crônicas por inquérito telefônico [Internet]. Brasília: Ministério da Saúde; 2014 [acesso em: 15 set 2017]. Disponível em: http://portalms.saude.gov.br/vigilancia-em-saude/ indicadores-de-saude/vigilancia-de-fatores-de-risco-e-protecao-paradoencas-cronicas-por-inquerito-telefonico-vigitel

12. Calcaterra V, Brambilla P, Maffè GC, Klersy C, Albertini R, Introzzi F, et al. Metabolic syndrome in Turner syndrome and relation between body composition and clinical, genetic, and ultrasonographic characteristics. Metab Syndr Relat Disord. 2014;12(3):159-64.

13. Carvalho Vidigal F, Ribeiro AQ, Babio N, Salas-Salvadó J, Bressan J. Prevalence of metabolic syndrome and pre-metabolic syndrome in health professionals: LATINMETS Brazil study. Diabetol Metab Syndr. 2015;7(1):1.

14. Qi W, Li S, Shen Q, Guo X, Rong H. Effects of recombinant human growth hormone therapy on carbohydrate, lipid and protein metabolisms of children with Turner syndrome. Pak J Med Sci. 2014;30(4):731.
15. Kohno H, Igarashi Y, Ozono K, Ohyama K, Ogawa M, Osada H, Onigata K, Kanzaki S, Seino Y, Takahashi H. Favorable impact of growth hormone treatment on cholesterol levels in turner syndrome. Clin Pediatr Endocrinol. 2012;21(2):29.

16. Giordano R, Forno D, Lanfranco F, Manieri C, Ghizzoni L, Ghigo E. Metabolic and cardiovascular outcomes in a group of adult patients with Turner's syndrome under hormonal replacement therapy. Eur J Endocrinol. 2011;164(5):819-26.

17. Hsieh S, Yoshinaga H. Abdominal fat distribution and coronary heart disease risk factors in men-waist/height ratio as a simple and useful predictor. Int J Obes Relat Metab Disord. 1995;19(8):585-9.

18. Ashwell M, Gunn P, Gibson S. Waist-to-height ratio is a better screening tool than waist circumference and BMI for adult cardiometabolic risk factors: systematic review and meta-analysis. Obes Rev. 2012;13(3):275-86.

19. Lam BC, Koh GC, Chen C, Wong MT, Fallows SJ. Comparison of body mass index (BMI), body adiposity index (BAI), waist circumference (WC), waist-to-hip ratio (WHR) and waist-to-height ratio (WtHR) as predictors of cardiovascular disease risk factors in an adult population in Singapore. PloS one. 2015;10(4):e0122985.

\section{Como citar:}

Farias SD, Fontenele EG, Quezado R, Quidute AR, Farias LA, Morita T, et al. A proposed waist to height ratio (WtHR) cutoff point for metabolic risk in Brazilian Turner syndrome patients. Rev Med UFC. 2018 out-dez;58(4):19-25. 